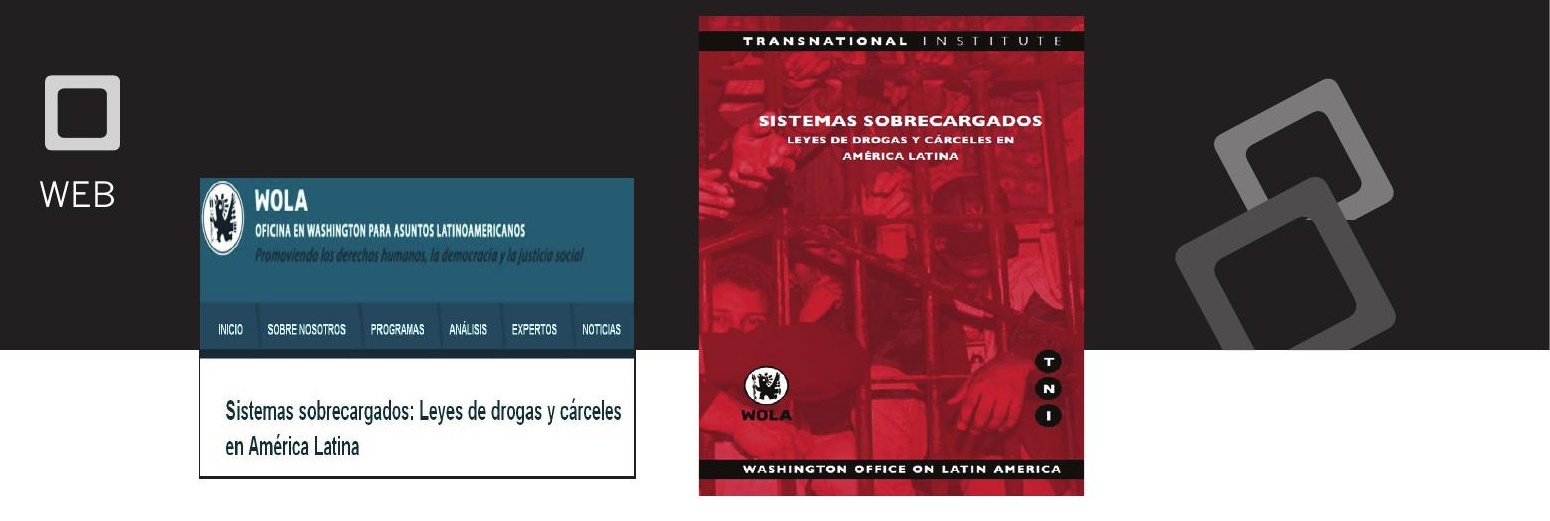

\title{
Sistemas sobrecargados: Leyes de drogas y cárceles de América Latina
}

\author{
Pien Metaal y Coletta Youngers (editores), \\ "Sistemas sobrecargados. Leyes de drogas y cárceles en América Latina", \\ WOLA y TNI, diciembre de 2010, ISBN/EAN: 978-0.9844873-5.6 \\ Tomado de: http://www.wola.org/es/informes/sistemas_sobrecargados_leyes_ \\ de_drogas_y_carceles_en_america_latina
}

A través del estudio de casos, las legislaciones de Argentina, Bolivia, Brasil, Colombia, Ecuador, México, Perú y Uruguay, son analizadas para comprender el funcionamiento de sus leyes con respecto al tema de las drogas; tanto el nivel de tratamiento penal, como el castigo y la sentencia, constituyen el principal objeto de reflexión y sus consecuencias a nivel macro social.

Para el lector amateur el tema, posiblemente se escandalice con los resultados presentados en esa investigación; en toda ella, con un rigor implacable, se muestra cómo los delitos relacionados a las drogas han incrementado el número de prisioneros en cantidades que pueden representar, incluso, altos porcentajes de población por nivel demográfico. Y sin embargo, lo que escandaliza, más que las estadísticas, es la manera en que los países estudiados, han tratado a sus prisioneros.

El documento, sin hacer ninguna clase de apología del crimen, demuestra con criterios del derecho internacional, cómo a través de un sistema judicial poco diversificado en cuanto a los niveles de transgresión que puedan considerarse, puede tenderse en una ingenuidad judicial, que crea un vacío que afecta al sistema social a largo plazo; es decir, la no-distinción de la gravedad de crímenes relacionados a la posesión, creación, distribución y venta de drogas, y su tratamiento punitivo por igual, ha provocado un hacinamiento sin precedentes, que está agotando los recursos carcelarios de los sistemas en los países analizados.

Si todo crimen implica un nivel de involucramiento, dicen los investigadores, no tiene por qué castigarse al simple consumidor, en comparación con un mando medio de una banda criminal reconocida internacionalmente; es así como el endurecimiento de las leyes debe poseer el equilibrio suficiente para no afectar al ciudadano común, quien suele ser la víctima más propicia, cuando cae prisionero en cualquiera de las legislaciones estudiadas.

Sin embargo, el documento se vuelve alarmante, a medida que analiza la inclusión de las drogas en la vida cotidiana; de tal manera que la cantidad de consumidores potenciales y su posibilidad de caer en el castigo, es más alta de lo que comúnmente se pueda pensar; y con la posible debilidad de las leyes en materia de drogas, un hecho cualquiera puede llevar a prisión a una persona, siendo esta susceptible de 
padecer penas máximas por delitos menores, creando una cadena que provocaría un mayor riesgo al prisionero, al verse expuesto dentro de la cárcel, a verdaderos criminales que buscan reclutar a más miembros para engrosar sus filas.

Sinopsis a cargo de Edwin Edgardo González Rodríguez Investigador y editor de textos académicos y literarios 